\title{
Entrepreneur: between the old and the new. Portrait of Romanian entrepreneur
}

\author{
Maria Irina Trofin (căs. Dromereschi), Technical College „Anghel Saligny” Bacău, România
}

\begin{abstract}
Difficult to capture in precise strokes of a definition of entrepreneur is not only linguistic but also chronological connotations. Entrepreneur or business leader or intraprenor, designer or manager, are all "hats" of entrepreneurship or a mood that is creating new business at risk pressure to obtain the expected profit. This explains the need to recognize such a character profile, characteristics and mode of action creates situations that they face. Amplification of entrepreneurship and thus increase the number of people who create their own business, own business have as motivators: independent lifestyle, consider entrepreneurs as heroes, demographics, increasing share of services, new technologies, cultivating entrepreneurship, development of the Internet and globalization. The transformation of a person into an entrepreneur is influenced by four variables: the situation, psychological, sociological and economic. These are all plans that are designed impregnated cultural entrepreneur personality in which it evolves and you need entrepreneur must assume. In Romania, entrepreneurship even encouraged, financed and newer - educated, is just beginning. Who is Romanian entrepreneurs who are its features and are accomplishments are some of his recent studies and research findings at the last minute. To what extent can help individual entrepreneur and social welfare are some of the questions answered theoretically predictable. Practically answer is incomplete.
\end{abstract}

\section{Keywords}

entrepreneur, entrepreneurship, entrepreneur Romanian.

\author{
Cod JEL: L26, M14.
}

\section{Chronology concepts of entrepreneur and entrepreneurship in economic literature}

It is argued in the literature that the entrepreneur is a key factor in making the pace and direction of change, as few other businesses can do. The term was originally used by the contractor Cantillon in the first half of the nineteenth century. It provides the first attempt to explore the entrepreneurial function in the economy. Entrepreneur's success lies in the ability to perceive and predict actions and reactions peers better than they can provide for his. The unique feature of Cantillon's entrepreneur is foresight and confidence to act under uncertainty (Casson, 1982). Cantillon's major contribution lies in the fact that he emphasized the existence of a third category of individuals than owners and workers. He gave a name to these people who are not involved in the production process and their contribution in terms of creating wealth is unobservable and intangible: entrepreneurs. He went on to give a systematic exposition of what distinguishes function Entrepreneurial behavior, showing that the contractor is initiating a project or activity is significant. Jean Baptiste Say the entrepreneur as a rare phenomenon that is able to coordinate and combine factors of production. Say's contribution in the wider area of business studies derive from associating 
entrepreneurship with the function of combining inputs in a production process. Thus, the main function of the entrepreneur is the central processing unit which receives information from a variety of sources and the production decisions. Say argues that "the contractor shall not be rich because they can work with borrowed capital, but must be at least creditworthy and have a reputation for intelligence, prudence, regularity and probity ... (Must have) a combination of moral qualities not often found together: judgment, perseverance and knowledge of the world. "(Say, 1964 (1803), p.285). Being a long period in the shadows, the entrepreneur has returned to the main character of economic inquiry during the twentieth century. Frederick Barnard Hawley tried to integrate contractor (identified by the developer) in the classical theory. Hawley's choice regarding terminology, calling its construction theoretical "risk theory of profit" and instead use the term entrepreneur entrepreneur, could explain the tendency to ignore the post-Knight by economists. Hawley motivatorul and conceptualize the entrepreneur as the bearer of uncertainty that will decide what will happen, how much and by what method to achieve their goals (Hawley, 1907). Schumpeter risktaking entrepreneur emerges: the latter is a function of the banking sector which capitalist or entrepreneur borrows money. Instead, the entrepreneur is defined as innovative individuals who introduce new combinations of factors of production. He argues that the essence of the entrepreneur lies in the perception and exploitation of new business opportunities ... always has to do with the approach of other uses of natural resources in that they are stolen from their traditional use and subject to new combinations (Schumpeter, 1928). Schumpeter goes on to identify five types of innovation: the introduction of a new good, the introduction of new production methods, opening a new market, the conquest of a new source of raw materials, creating a new type of industrial organization. Therefore anyone performing any of these functions - either independent businessman or manager of a larger organization, is an entrepreneur. 1949 Schumpeter goes on to differentiate between entrepreneurship and entrepreneurial function. Distancing himself from Labour's tripartite division of Say, Schumpeter identifies a class division between invention and entrepreneurship: the latter being characteristic of businesses that make things work (Say's application) while first being of those employed in production of new ideas (scientific) (Say's abstract work). Ideas generated by the inventors themselves are not of any importance for economic activity (Schumpeter uses the example of the ancient Greeks who produced all that is needed to create a steam engine but built itself one), as not all innovations should incorporate something that is new in scientifically (Schumpeter, 1947). Even though in some cases the invention and entrepreneurship are combined by the same trader, however, they remain distinct analytical categories. Similarly, Schumpeter provides a clear distinction between management and entrepreneurship. The first is perceived to be a simple matter essentially a management problem if combinations that took place in the past should simply be subject to customary adjustments that generates business experience before conditions change under the influence of external factors [...] but if we believe in Say's definition where combinations that are not inherited from the past must be set again, then the situation is different and we really have before us a distinct function (Schumpeter, 1949). Distinguishing feature of the invention, entrepreneurship and management Schumpeter emphasizes the importance of the former. He argues that the entrepreneur changes the rules of the game, combining resources in new ways and thus establishes a new production function (Martinelli, 1994). He explores the revolutionary character of the entrepreneur with the same admiration you show proletariat Marx. In fact, Schumpeter is responsible for the design entrepreneur as a heroic figure of capitalist development. So, talented entrepreneurs are rare. It's not a surprise that they are now - in the generalized and chronic economic crisis - the solution considered as critical points of the economic cycle and the medium and long term. Max Weber's work on entrepreneurship is part of wider research that explores the origins of economic knowledge and specific content of religious belief. Weber (1922) distinguishes between capitalist and entrepreneur historical predecessors. Capitalist entrepreneur is involved in a rational and systematic process of economic gain, his calculations are measured in relation to the 
economic criteria, earn their trust through honesty and subordinated to the interests of capital accumulation consumption. Rationalize every aspect of the entrepreneurial process (defined as instrumental rationality) is what characterizes the capitalist entrepreneur. To answer the question: what motivates the capitalist entrepreneur, Weber indicates the importance of religious creditors. It identifies the Protestant ethic as a key factor in motivating the capitalist entrepreneur: it emphasizes the intrinsic value of labor. In this context, the work of an individual is regarded as a calling in assigning literal concept of vocation. Moreover, the Protestant ethic financial reward for their work as an expression of divine blessing. At the same time, however, demanded austerity Protestant values and accumulation of productive assets (Weber, 1922). Momentum transformation Protestant ethic motivated by true entrepreneurial action is due to the development of experimental science, rational authority from Roman law and government administrations rational (Kilby, 1971). Austrian School offers one of the most consistent and suggestive theoretical construction entrepreneurial studies. Radical subjectivism, methodological individualism and motivation of human action were used persuasively to strengthen our understanding of the function of entrepreneurs in market processes. Continuity (Mises-Hayek-illustrated by Kirzner) and the development of ideas through generations of Austrian school led to the growing importance of this topic. A defining attribute of entrepreneurial action is that it has a purpose, that action is put into operation and transformed into useful results, aiming to achieve certain goals and objectives is the ego meaningful response to the stimulus and its environmental conditions. (Mises, 1966). Mises's entrepreneur is a complex creature undoubtedly an individual both in terms of goals behind, but also in terms of the structure of the mind and its experiences. Led by an inherent dissatisfaction about its ability to meet its goals, the contractor has the ability to imagine new combinations of meaning in the face of uncertainty. Thus, the actions of entrepreneurs are full of purpose and rational. Actions may be wrong but are derived rationally. In fact, erroneous actions of an entrepreneur are market opportunities for another. This conceptualization is profoundly different, less heroic but more inclusive than that offered by Schumpeter making us look beyond innovation entrepreneurship. At the same time, however, requires a set of alternative restrictions, excluding any investigation of change instigated by the contractor. Indeed Mises's entrepreneur is responsive to the challenges offered by specific situations. Moreover, the impact of the external environment in particular institutional setting - has on entrepreneurial activities, recognized, remains unexplored way since knowledge of a collective structures by analyzing individual actions (Mises, 1966). Hayek focuses on the concepts of information and knowledge, rather than on entrepreneurial decision making problem. He starts to identify ways in which individuals involved in complex and expanding division of labor, successfully coordinate their actions when each individual has only local knowledge and idiocratică (Foss, 1994). Thus, a key element in Hayek's discussion about the process of learning was what he saw as a problem of the division of knowledge (Hayek, 1937), meaning that different economic agents know different things. Availability information is only the first of constraints on individual decisions. Ability to process information (what Hayek called mental processing) offers another set of constraints. This puts considerable pressure of time, physical endurance, consciousness, mind and senses capaciăţii entrepreneurs (Tansey, 2002). Hayek sees the world in which there is a continuous process of discovery. Entrepreneurial discovery process description shows that individuals and companies are surrounded by pre-existing theories which are interpreted in the light of events. Experineţei perceptions species accumulated (knowledge) are modeled universal influence an individual's own experience. This, combined with the fact that access to information is partially located are arguments supporting the idea that entrepreneurs are key operators in acquiring information and knowledge and the search for equilibrium prices. Entrepreneurs generate hypotheses tested is then confirmed or rejected. Kirzner's theory is explicitly founded on the ideas developed by Mises (Human Action) and Hayek (information and knowledge). Naturally alert to the potential profit oporunităţi is the defining attribute of entrepreneurs practitioners. 
Entrepreneurial opportunities are created for earlier errors that resulted in deficits, surpluses, mis-allocated resources. Entrepreneur alert, bold discovered these errors and when they were made, buying where prices are low and selling where prices are high (Kirzner, 1997). Earlier entrepreneurial errors combined with continuous change in taste, handy resources and technological developments mean that opportunities for entrepreneurial profit are present in each market. In this context, the process by which opportunities are observed and collected in an inherently unsafe environment is the essence of the market economy. Consequently, Kirzner advancing the notion of entrepreneurial discovery. The starting point of his approach is the conceptualization of Hayek on the market as a process of mutual discovery continues. Discovery differs from neo-classical building by bending the notification and opportunity plus the realization that something was overlooked fact already available (Kirzner, 1997). Thus, the entrepreneur is always engaged in a systematic scanning the market for opportunities, without knowing exactly what you are looking for. Alert entrepreneurship refers to an attitude of receptivity to opportunities available - but so far neglected. Each finding is accompanied by a sense of surprise of what the contractor neglected aterial. Mark Casson develops an economic theory of the entrepreneur who is inspired by neo-classical theoretical constructions. By doing so he admits emotional significance rewards and costs of accessing information, while remaining detached from the idiosyncratic nature of early scientists (Schumpeter and Kirzner) on motivation contractor that are incompatible with rational action (Casson 1998). Novelty compared to the neo-classical assumptions begins with the recognition that individuals differ not only in taste but also in their access to information (Casson 1982). Minded individuals acting in similar circumstances, but with different information at their disposal, can make different decisions. This is due to the fact that information is costly, so individuals can choose to make decisions based on very limited information and partly because interpretation of the information may be different since you individuals use their own cognitive frames. (Casson, 1998). It is important to emphasize that the data processing Casson differ significantly different from that offered by Kirzner and Mises. While the latter refers to information that individuals do not know that there (hence the element of surprise), the first refers to information available known as a cost to be produced (Stiglity 1994). Summarizing, entrepreneurship has a different perception of the situation due to different access to information. The decision to act is up optimism and confidence that drives entrepreneurial behavior. Thus, the demand for entrepreneurship (ie number and nature of entrepreneurial roles, opportunities - that must be seized and exploited) is very subjective. (Casson, 1993). Providing entrepreneurs is governed by occupational choice. Based on neo-classical models developed by Lukas (1978) and Kihlstrom and Laffont (1979), Casson suggests that the decision to become an entrepreneur is influenced, at least partially, the rewards of entrepreneurship possible about salary levels. This could be graphically represented by a neoclassical supply curve. However, Casson thesis expands its position by arguing that the supply curve depends on the number of entrepreneurs capable, which in turn is determined by the distribution of wealth, education organization, social structure, degree of social mobility and the institutionalist (Casson, 1982). D.H.'s approach Harper, a student of Mark Casson, is a significant departure for radical subjectivity that extends beyond the Austrian tradition and is influenced by Popper's idea of increasing the level of knowledge. Its starting point is the recognition that learning processes are crucial to all phenomena that economists try to explain. Thus, he begins to establish a dynamic theory of entrepreneurial learning. Harper Entrepreneurship is defined as a profitseeking activity in order to identify and solve specific problems in complex and uncertain situations. It involves discovering and creating new frames containing goals rather than allocating certain meanings given search targets (Harper, 1996, p 3). Entrepreneur is an agent seeking to break the routines established and the existing range of ideas. Increasing knowledge is oragnizată around a core group proposals. Unit of analysis is the individual, because only individual businesses have goals, circumstances and preferences and make decisions. However individuals when faced with a problem, do not necessarily know the 
parameters. Instead, individuals should try to gain understanding - is constructed subjectively - despite the fact that objective reality exists. More importantly, however, there is no test method even if someone has found the truth. Thus, businesses are fallible simply by their inability to test assumptions underlying their actions. In response, individuals make tempting solutions to problems in a world of structural uncertainty, complexity and real time and learn from the feedback provided by successive decisions. However, feedback is rarely optimal or perfect. Thus, while not possessing true knowledge antreprenoriii demonstrated, however, they can make rational decisions. Rational decision making in this context means the assessment schemes in the light of logic and experience. In the last 25 years, research driven entrepreneurial business schools has become increasingly dominated by evolutionary approach. Erik Stam (2002) aimed to explore the issue of the context in which the entrepreneur operates. Stam's work focuses more on individuals rather than groups. Furthermore, analysis of institutional evolution and geography combined with time - derived from economic geography. While recognizing the merits of entrepreneurial personality and training organization, he examines entrepreneurship as a contextual phenomenon. This allows him to perceive entrepreneurs as individuals who act within certain social and physical contexts and living in specific times and locations. The institutional analysis of his work is perceived largely in terms of theoretical lines of the new institutionalist economics of Williamson and North. Formal and informal Insituţiile gives intsrumentele we need to unravel the maze of social relations. He emphasizes institutionalization, seen as a process that imposes constraints on entrepreneurial businesses which, in turn, have the ability to implement change in the institutional plan. Analysis provides tools to explore evolutionary change within the system. It makes it possible explanation on how the forms of organization and behavior emerge and evolve in socio-economic conditions. Stam adopts an essentially Darwinian relating to human reflexivity and appropriate action. Also, time geography is an approach in which time and space are not seen as a combination of two dimensions but as a framework for analysis. The main starting point in time geography (or "geo-historical analysis" as it is sometimes called) is that "the time, place and something happens that affects the way that happens" (Stam, 2002, p 8). The approach developed by Stam trying to bring unity of space, time and process. Although superficially described in a short paper, it gives a suggestive research on the study of entrepreneurship. One of those issues that raise concern about the explanatory power of the argument developed by Thornton and by Stam is the action. More specifically, to what extent and how businesses can act independently of the context in which they operate. What are the factors and processes that facilitate timely action despite social determinism? Under what circumstances is prescribed behavior or contextual entity free will?

\section{Portrait of Romanian entrepreneurs}

Gallup Organization study in Romania, in January 2005 made with interactive training company in Bucharest (using Hofstede's methodology) made up portrait of the entrepreneur, employee, manager and Romanian leader in an organization. Power distance index of authors called power complex says that people obey authority and not a contest, it is related emotional devotion and dependence either be negative as by hatred and counter-dependency. The other facet of this dimension is complex authority may explain the refusal by most Romanians obstinenţă and unreported to respect the laws and authority, and at the same time express request of laws and rules. Individualism level shows that the groups to promote their members' interests at the expense of other groups, "us" against "your" and excluded by each individual multiplication of resources. The trend observed is that the degree of individualism is increasing due to population identified by Hofstede correlation between individualism and funding received by the country (increase confidence in the ability of individuals to create added value to begin to learn self-sustaining economic). Romanian femininity shows that members of society seeking a collaborative environment and require support of all members 
of society, regardless of their contribution. The downside of this indicator shows that feminine values of society determines a lower level of competitiveness of local organizations to those in foreign markets, valuing leisure female personal values and cooperation at the expense of performance objectives. The authors identify as a possible source of the high index, Orthodox religion (dominant) that gender complementarity is more inclined than women's subordination to men. Hofstede notes that while the services that have high added value that can not be mechanized and requires the presence of human factor will require learning of feminine values. Uncertainty Avoidance Index shows that the population has a high degree of anxiety about the future and safety of today prefer the uncertainty of tomorrow. Anxiety level and pressure creates favorable impulse, haste and negative emotion expression without control. The authors identify historical argument and repeated foreign rule in combination with the high level of collectivism as necessary to explain the high degree of anxiety Romanians. Short-term orientation in Romania shows an inclination to present and past (original orthodoxy in Christianity and Confucianism unlike practicing virtue and making efforts today to obtain results tomorrow) at the expense of investment in the uncertain future, and low saving for the future. Short-term oriented societies live mainly in debt instruments. Romanians will be very difficult to plan long term and will prefer the innovative trodden paths. Short-term orientation is at the root of the low level of capital invested and partly explains the need for rich quick. The authors warn anachronism model "family" that entrepreneurs seem to prefer because they have not enough knowledge to create a clear structure in the long term. Moreover, this model oriental favor nepotism and corruption organization to employees due to centralization of authority. Persists in these patterns, entrepreneurs risk losing potentially valuable employees (autorealizării dissatisfaction expected), keep employees were "adapted" by psychological corruption (avoiding responsibilities and risky actions and praising effort contractor) or to create mechanisms internal corruption (favoritism and hiding actual performance). In the process of EU accession, the difference that worries most is complex and authority tend duplicity and dissociation between statements and actions. Standardization imposed by the EU will be a good win and subsequently appreciated. Certification, quality standards, rules and procedures will be refused although initially will be further treated with devotion. There are sufficient reasons why many people choose to engage in business on his own instead of employee status. Most often, entrepreneurship is seen as an opportunity or as a means of subsistence in the absence of an alternative or fear of becoming unemployed in a future perspective. As opportunities are declared desire for independence and financial gain higher than for an employee. A separate category is motivated by necessity entrepreneurs who say they have found another way to earn a living. Opportunity oriented improvement refers to those entrepreneurs who appreciate independence and seek to continuously improve standards. This type of motivation is most common in innovation oriented economies. Entrepreneurial motivation analysis report submitted by GEM 2011 shows that the share of early stage entrepreneurs are motivated by opportunities of $67.3 \%$ and twice the value recorded for early stage entrepreneurs motivated by necessity. It can be concluded that more than two-thirds of early stage entrepreneurs are motivated by opportunities. The analysis summarized in Romania show changes in entrepreneurial aspirations, as follows: decreased level of expectation on the rapid growth of early stage entrepreneurial activity from $0.07 \%$ in 2007 to $0.27 \%$ in 2009 among the population aged 18-64 years back growth expectations slightly to $0.48 \%$ in 2010 , a slight increase in the market for new products by $22.4 \%$ and an orientation towards internationalization level increase to $28.5 \%$ in 2010 . From 1995 to present, Romanian entrepreneur profile improved in terms of the ratio between men and women entrepreneurs, education, technical skill and entrepreneurial experience. From a gender perspective, almost two thirds (63.4\%) of entrepreneurs who have set up a business on his own in 2008 were men. Although the percentage of Romanian entrepreneurs remained positive men, the difference between the number of female entrepreneurs and male entrepreneurs number in Romania decreased gradually until 2008. Regarding educational 
level, $53.9 \%$ of Romanian entrepreneurs are high school and university graduates, while $1.7 \%$ of them completed only primary education level. Percentage Romanian entrepreneurs, graduates of secondary schools and universities experienced a rising trend since 1995. Hence, the content of school curricula result of focusing on developing a culture and entrepreneurial skills to be improved in higher education, regardless of area of specialization. Improving education entrepreneurs create a favorable to develop dynamic companies. Romanian entrepreneurs skill level has improved in recent years, the proportion of unskilled workers who set up their own businesses decreased to one third in 2008 to two-thirds what it was in 1995. However, the level of managerial experience of the founders / managers of enterprises is still very low, only $2.4 \%$ of start-ups (startup) in 2008 were started by entrepreneurs with previous experience in managerial positions. This lack of managerial experience must be complemented by vocational training (CVT) or oriented disciplines including management / entrepreneurship education into the curriculum of technical and scientific universities, given the research conducted by INS data, which show that more than half of Romanian entrepreneurs have completed higher education level. Impact of financial crisis on the problems faced by entrepreneurs was passed in difficulties with access to finance. In 2008, the share of new firms without resources amounted to $77.1 \%$, the percentage of those with problems caused by delays in payments by customers reached $49.7 \%$, and those with limited access to bank loans reached $47.2 \%$. However, the difference between financial difficulties and other problems become more pronounced offer: more than $20 \%$ of entrepreneurs faced difficulties related to the lack of technology, lack of access to skilled employees or raw materials. Survival is the most important issue for start-ups and entrepreneurship development in Romania. However, most of the new firms that survive or remain in the category of micro, or in the best case evolves as the class size small. Very few of them are able to develop a medium enterprise level in a short period of time. This latter group of companies called dynamic entrepreneurial projects or, less formally, "gas", are responsible for creating the largest number of jobs, innovation and added value to the socioeconomic environment. Therefore, public policies to support entrepreneurship should distinguish between traditional businesses and the potential for rapid growth and provide mechanisms for the creation and development of "gazelles", especially in less developed areas of the country. The study reveals that the entire population of firms, a relatively small segment - fast growing companies - provides a major part of newly created jobs along with a considerable amount of turnover. Analysis results lead to the conclusion that to accelerate entrepreneurial growth, a policy should be directed at increasing productivity through entrepreneurship education and key skills qualifications which replace facilitating access to finance. Based on the number of companies active in Romania, as the main indicator of entrepreneurship, we can see the impact on employment and contribution to value added as comparative data with average values recorded in the European Union. SMEs are numerical majority holding a $99.7 \%$ share of the total number of active enterprises in the economy in Romania, similar proportion of EU-27. They have a significant contribution of $65.9 \%$ in total number of employees and is located very close to the average of SMEs in the European Union (66.9\%). SMEs in Romania participates at a rate of 50.2\% in gross value added in the economy, a lower percentage compared to the EU average 58.4\%. According to the analysis contained in a recent European Commission study, entrepreneurship education has a positive impact on entrepreneurship of the young generation, the attitude and willingness to private initiative and ultimately its role in society and the economy. Entrepreneurial skills that can turn ideas into actions include: creativity, innovation, risk taking and project management ability and success. Furthermore, it helps to understand a given context and assessment opportunities so determines entrepreneurship and starting a business. According to the same study, the objectives of entrepreneurship education are related to improving young people's entrepreneurial skills, creativity and self-confidence, encourage innovative startups, increasing the role of entrepreneurs in society and the economy. Although entrepreneurial knowledge necessary for learning is growing, there are still a number of obstacles in the 
development of entrepreneurship education, especially in terms of finance and human resources. Entrepreneurship education is one of the main determinants for entrepreneurship. It plays a major role in key business skills, having a positive impact on entrepreneurship of the young generation, the attitude and willingness to private initiative. Romania is among the few European countries that do not yet have a national strategy for entrepreneurship education. Although the past 10 years have been implemented initiatives to promote entrepreneurship education, both in the national education system as well as various training programs, actions in this direction are scattered, with no coordination and coherence between them.

\section{Conclusions}

The contribution of entrepreneurship to increase economic performance and well-being and social cohesion can be easily evidenced by the relationship between the values of the indicators for entrepreneurship and macroeconomic outcomes. The reality of the impact of entrepreneurship on the economy and society globally recognized through studies and reports from international bodies are confirmed in Romania with regional analysis. Internationally, entrepreneurship is widely recognized as a generator of wealth in society and crucial factor for economic growth and job creation. Supporting entrepreneurship has become a priority in recent years and is considered a solution to the crisis and stop worrying unemployment rate. In the European Union, entrepreneurship is included in national programs for vocational education in most Member States, but entrepreneurship is not related to certain subjects or certain professions and, therefore, should be viewed in a general approach to the strategic level of any countries. Although entrepreneurial knowledge necessary for learning is growing, there are still a number of obstacles in the development of entrepreneurship education, especially in terms of finance and human resources. Despite some encouraging elements, it appears that the uptake and effectiveness of entrepreneurship education in schools is still far from being fully satisfactory.

\section{Bibliography}

1. Baumol, W.J., "Entrepreneurship: productive, unproductive and destructive",Journal of Political Economy, volume 98, number 5: $893 \quad-\quad 921, \quad 1990$. Disponibil pe http://wwwecon.stanford.edu/academics/Greif_228 2007/Baumol\%201990\%20JPE\%20Entrepreneurs hip.pdf Accesat pe 16/10/2011.

2. Berger, B., "Introduction", în Espirit d'entreprise, cultures et societies, Paris: Maxima, 1993, pp.114.

3. Bosma, N., Levie, J., Global Entrepreneurship Monitor. 2009 Executive Report, Babson College, Universidad del Desarrollo, Reykjavík University, London Business School and Global Entrepreneurship Research Consortium (GERA), 2010.

4. Bourdieu, P., Practical Reason: On the Theory of Action, Stanford University Press, Stanford, 1998.

5. Braudel, F.,,Histoire et sciences socials.la longue duree", in F.Braudel, Ecrits sur l'histoire, Flammarion, Paris, 1958/1996, pp.41-48.

6. Bygrave, W., Hofer, C.W., Wilken, P. (1979). Entrepreneurship: A Comparative and Historical Study. Norwood, N.J.: Ablex Publishing Corp.Theorizing about entrepreneurship, Entrepreneurship Theory and Practice, Winter, 1991.

7. Cantillon, R., Essai sur la Nature du Commerce en General(1755), Ed. H. Higgs, London: Macmillan, 1931, pp. 54-56.

8. Carlson, N., Psychology. The Science of behavior, Allyn and Bacon, Boston, 1993.

9. Casson, M., The Entrepreneur, Totowa, NJ, US: Barnes and Nobles Books Ellsberg, D., „Risk, ambiguity, and the Savage axioms", Quarterly Journal of Economics, 75, 1982.

10. Casson, M., "The Individual-Opportunity Nexus: A Review of Scott Shane: The General Theory of Entrepreneurship." Small Business Economics 24(5): 423-430, 2005.

11. Choi, I., Nisbett, R.E., Smith, E.E., "Culture, categorization and inductive resoning"in Cognition, 65,1997, pp.15-32. 
12. Drucker, P., Inovaţia şi sistemul antreprenorial, Editura Enciclopedică, Bucureşti, 1993 .

13. Drucker, P. F.,Societatea postcapitalista, Editura Image,Bucureşti, 1999.

14. Gartner, W. B., Who is an entrepreneur? is the wrong question. Entrepreneurship, Theory and Practice, 13, 4:47-68, 1988.

15. Hayek, F.A., "Economics and knowledge", Economica (N.S.) 4, 1937, pp.33-54, reprinted in F.A. Hayek, Individualism and Economic Order, London, Routledge and Kegan Paul, 1959, pp.33-56.

16. Hayek, F.A., "Richard Cantillon", The Journal of Libertarian Studies, volume VII, number 2, Fall 1985: 217 - 247, 1931 . Disponibil pe http://mises.org/journals/j1s/7_2/7_2_2.pdf Accesat pe 9/09/2011.

17. Hawley, F.B., Enterprise and Productive Process, New York: G.P. Putnam's Sons, 1907.

18. Hofstede, G., Managementul structurilor multiculturale. Software-ul gândirii, Editura Economică, București, 1991, 1996.

19. Hoselitz, B.F., "The early history of entrepreneurial theory", Explorations in Entrepreneurial History (Series 1), 3, 1951, pp. 193-220.

20. Kets de Vries, M. F. R., , The entrepreneurial personality: A person at the crossroads, The Journal of Management, 1977, Studies 14 (1), 34-57.

21. Kilby, P. (ed) Entrepreneurship and economic development. New York: Free Press, 1971.

22. Kirzner, J.T., "Comment: X-inefficiency, error and the scope for entrpreneurship", in M.J.Rizzo (ed.), Time, Uncertainty and Disequilibrium, Lexington, Mass: D.C.Heath, 1979b, pp.140-151.

23. Kirzner, I.M., "Creativity and/or alertness: a reconsideration of the Schumpeterian entrepreneur", The Review of Austrian Economics, 11: 5 - 17, 1999. Disponibil pe http://ideas.repec.org/a/kap/revaec/v11y1999i1-2p5-17.html Accesat pe 7/08/2011.

24. Knight, F.H., "Profit and entrepreneurial functions", the Tasks of Economic History: Supplement to Journal of Economic History, 2, 1942, pp,126-132.

25. Knight, F.H., Risk, Uncertainty and Profit, Kelley and Millman, New York, 1957.

26. Lachmann, L.M., "From Mises to Schackle: an essay on Austrian economics and Kaleidic Society", Journal of Economic Literature, 14, 1976, pp. 54-62.

27. Mises, L. von, Human Action: A Tretise on Economics, London: William Hodge, 1949.

28. Mises, L. 1957. Theory and history, reprinted in 2000. Yale University Press: New Haven, Conn. Online Edition Ludwig von Mises Institute. Disponibil pe http://mises.org/th.asp Accesat pe $10 / 09 / 2011$.

29. Mises, L., 1969. The historical setting of the Austrian school of economics, 2003 Online edition by the Ludwig von Mises Institute. Disponibil pe http://mises.org/etexts/histsetting.pdf Accesat pe 6/09/2011.

30. Say, J.B., A Tretise on Political Economy: or, The production, Distirbution and Consumption of Wealth (1803), New York: Augustus M.Kelly, 1964.

31. Schumpeter, J.A., "Economic theory and entrepreneurial history", în H.G.J. Aitken (ed.), Exploration in Enterprise, Cambridge, Mass: Harvard University Press, pp.45-64.

32. Schumpeter, J.A. 1942a. "Creative destruction", in Schumpeter, 1975, Capitalism, socialism and democracy: $82 \quad-85 . \quad$ New York: Harper. Desponibil pe: http://transcriptions.english.ucsb.edu/archive/courses/liu/english25/materials/schumpeter.html Accesat pe 3/10/2011.

33. Thornton, M., 1999. "The origin of economic theory: A portrait of Richard Cantillon (1680 1734)", in Holcombe, R. (ed.), 15 Great Austrian Economists: 13-28. Alabama: Ludwig von Mises Institute Auburn University. Disponibil pe http://www.asiaing.com/15-great-austrianeconomists.html Accesat pe 13/08/2011.

34. Thornton, P. H., The sociology of entrepreneurship. Annual Review of Sociology, 25:19-46, 1999.

35. Von Mises, L. (1966) Human Action, 3rd rev. ed., Henry Regnery, Chicago.

36. Weber, M.(1976) The Protestant Ethic and the Spirit of Capitalism. Allen and Urwin. London.

37. Correlation Analysis on Entrepreneurial Culture and Region Economy Development, The Sixth Wuhan International Conference on E-Business, Innovation Management Track, pp.2393-2398.

38. http://www.postprivatizare.ro/romana

39. Comisia Europeană, Strategia Europa 2020.

40. Comisia Europeană, Consultation on an Entrepreneurship 2020 Action Plan, 2012.

41. Comisia Europeană, Study on the SMEs' impact on the EU labour market, COM 16/01/2012

42. Institutul Naţional de Statistică, Anuarul Statistic al României, 2011. 